International Research Journal of Management, IT \& Social Sciences
Available online at https://sloap.org/journals/index.php/irjmis/
Vol. 6 No. 6, November 2019, pages: 50 57
$\begin{aligned} & \text { ISSN: 2395-7492 } \\ & \text { https://doi.org/10.21744/irjmis.v6n6.752 }\end{aligned}$

\title{
Effect of Budgetary Participation in Managerial Performance with Environmental Uncertainty, Leadership Style, and Budgetary Adequacy as a Moderating Variable
}

\author{
Damaris Ussy Tokilov ${ }^{\text {a }}$ \\ I Dewa Gede Dharma Suputra ${ }^{\text {b }}$ \\ Ni Ketut Rasmini ${ }^{c}$
}

Article history:

Received: 27 May 2019

Accepted: 31 July 2019

Published: 27 September 2019

\section{Keywords:}

budget adequacy;

budget participation;

environmental;

leadership style;

uncertainty;

\begin{abstract}
The purpose of this study was to examine the effect of budgetary participation on managerial performance with environmental uncertainty, leadership style, and budget adequacy as a moderating variable. This research uses contingency theory and Participative Decision-Making theory. The sampling technique used was purposive sampling, so the number of samples was 22 companies. Data analysis techniques using the Moderated Regression Analysis analysis technique. The results of this study indicate that the first hypothesis which states that budgetary participation influences managerial performance shows that a significant level of 0.002 is smaller than $\alpha=0.05$, indicating $\mathrm{H} 1$ is accepted, which means that budgetary participation has a positive effect on managerial performance. The second hypothesis shows that a significant level of 0.037 less than $\alpha=0.05$ signifies H2 being accepted, which means that environmental uncertainty reinforces the influence of budgetary participation on managerial performance. The third hypothesis shows that the significance level of 0.854 is greater than $\alpha=0.05$, which means that the leadership style weakens the influence of budgetary participation on managerial performance. The fourth hypothesis shows that the significance level of 0.863 is greater than $\alpha=0.05$, which means that the budgetary adequacy weakens the influence of budgetary participation on managerial performance.
\end{abstract}

2395-7492@ Copyright 2019. The Author. This is an open-access article under the CC BY-SA license (https://creativecommons.org/licenses/by-sa/4.0/) All rights reserved.

\section{Author correspondence:}

Damaris Ussy Tokilov,

Fakultas Ekonomi dan Bisnis Universitas Udayana, Denpasar, Indonesia.

Email address: maris_ussy89@yahoo.co.id

${ }^{a}$ Universitas Udayana, Denpasar, Indonesia

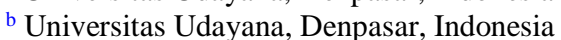

${ }^{\mathrm{c}}$ Universitas Udayana, Denpasar, Indonesia 


\section{Introduction}

This research is based on the Participative Decision-Making Theory. Haryanti (2012), defines participative decision making as employee participation in organizational decision making, which is a formal, operative tool in voicing the opinions and views and decisions of these employees. Based on Participative Decision Making Theory, managers/officials at the regional level can channel their opinions regarding what is needed or what must be done by the work unit in order to achieve the goals, vision, and mission of the organization. Budgeting is one means to participate in decision making.

Participation in budgeting is considered as a managerial approach that can improve organizational performance. Subordinates who feel their opinions are valued and have an influence on the budget prepared will have more responsibilities and moral consequences that improve performance as targeted in the budget. The effect of environmental uncertainty on managerial performance will be determined by the level of sophistication of the management accounting system information and the level of decentralization. When environmental uncertainty is low, management can make relatively accurate predictions about the market that can be guided from the general parameters of management accounting and conventional accounting information systems. In addition, there are a few types of information that are critical and important for decision making. Under these conditions, the environment can be interpreted more easily because various sets of rules are available and can be accommodated in traditional management accounting systems.

According to Gul \& Chia (1994), if a management accounting system is very sophisticated (in terms of scope and a system and has more role in achieving performance) so the reports presented contain more non-economic and nonfinancial information and are of greater benefit for forecasting and decision models, managers will be burdened with information overload that can result in decisions that are not optimal. Consequently, this condition will negatively affect managerial performance.

When environmental uncertainty is high, organizations may need additional information to anticipate environmental complexity. According to Gul \& Chia (1994), the more sophisticated the reports generated from management accounting system information will be able to help reduce uncertainty and improve the quality of decisions made which may further improve managerial performance.

The right leadership style is directed towards openness and is more humanistic, which by Coster \& Fertakis (1968), is called consideration. The results of his research indicate that the leadership style has a positive impact on the existence of a budgeting drive. The effectiveness of budgetary participation is strongly influenced by the management leadership style (Fiedler, 1967). Musyarofah (2004), found that the significance of the interaction coefficient of strategic change and management style cannot be used as indicators to determine the effect of the interaction between strategic change and management style on organizational performance.

Budgetary adequacy is an employee's belief that they have enough budget to work in accordance with their duties and functions. If employees believe that the organization is responsible for ensuring that employees receive sufficient budgetary support, then the budgetary adequacy might increase employee ties to the organization (Nouri \& Parker, 1998; Putri \& Sujana, 2018). Nouri \& Parker (1998), argue that workers with budget support generally have better performance than workers who are not supported with budgetary adequacy.

\section{Literature Review and Hypothesis}

Yusfaningrum \& Ghozali (2005), have conducted research to examine the relationship of budgetary participation with managerial performance through a commitment to budget goals and JRI as an intervening variable, also to examine the direct effect of budgetary participation on managerial performance. Their results show that there is a positive and significant relationship between the influence of budgetary participation on managerial performance directly. Lestari (2008), has conducted research to examine the effect of budgetary participation on managerial performance. The results of his research indicate a positive and significant relationship between budgetary participation and managerial performance. While the results of Milani (1975); Kenis (1979); Yanti \& Dwirandra (2019); and Riyanto (1997), show that there is no significant relationship between budgetary participation and managerial performance. Based on the findings of previous studies, this study examines the effect of participation in budgeting on managerial performance. H1: Budgetary participation has a positive effect on managerial performance.

Tokilov, D. U., Suputra, I. D. G. D., \& Rasmini, N. K. (2019). Effect of budgetary participation in managerial performance with environmental uncertainty, leadership style, and budgetary adequacy as a moderating variable. International Research Journal of Management, IT and Social Sciences, 6(6), 50-57. https://doi.org/10.21744/irjmis.v6n6.752 
Environmental uncertainty is related to the broad scope of management information systems such as economic information, total market sales, and company market share, non-economic information such as demographics, consumer tastes, competitors' actions and technological advances (Chenhall \& Morris, 1986). Many difficulties are caused by environmental uncertainties that affect planning and control. For an organization, the main source of environmental uncertainty comes from the environment, which has competitors, consumers, suppliers, regulators and the technology needed (Kren, 1992). Environmental uncertainty is one factor that often causes organizations to make adjustments to the conditions of the organization with the environment. Environmental uncertainty is the perception of members of the organization. A person experiences uncertainty because he feels he does not have enough information to predict the future accurately (Falikhatun, 2007; Lamba et al.,2019).

H2: Environmental uncertainty strengthens the effect of budgetary participation on managerial performance.

Leader Orientation is a choice made by leaders in an organization oriented to relationships or through tasks. Leader Orientation is known from the semantic differential scale of the most disliked partners in the organization (Least preferred coworker $=$ LPC). High LPC if the leader does not like coworkers, while a low LPC shows a leader who is ready to accept co-workers to work together. A high LPC score shows that the leader is relationship-oriented, whereas a low LPC score indicates that the leader is task-oriented. Situation favorability is a measure of the extent to which the leader can control a situation, which is determined by 3 situation variables. Three aspects of the situation considered include the leader-member relationship, position power, task structure. The results of Coster \& Fertakis (1968), show that the leadership style of the consideration has a positive impact on the existence of a budgetary push. Sumarno (2005), in his research stated that the effectiveness of budgetary participation on managerial performance is strongly influenced by the management leadership style. Based on the previous description, the following hypothesis can be arranged.

\section{H3: Leadership style strengthens the effect of budgetary participation on managerial performance}

Research conducted by Paters (1971), found the budgetary adequacy as one of the situational factors that will affect managerial performance. Managers and employees with budgetary adequacy support will be able to achieve higher performance than managers and employees sign of adequate budget support (Supriyono, 2004). With budgetary adequacy needed, it is expected that managers will work their best to run the planned program or the tasks that become their obligations. Nouri \& Parker (1998), state that employees with adequate budget support will, on average, show higher performance than employees without adequate budget support and prove that there is an effect of budgetary adequacy on performance. However, different results obtained in the study of Sinuraya (2011), which states there is no relationship between budgetary adequacy and improved performance. Based on the previous description, the following hypothesis can be arranged.

H4: Budgetary adequacy strengthens the effect of budgetary participation on managerial performance.

\section{Materials and Methods}

The location of this research was conducted at a construction service company incorporated in the Indonesian Buton Asphalt Association in (AABI), Bali Province, which is a private agency that provides services to the community, especially road infrastructure services. The choice of location was made because researchers were interested in the findings of managerial performance at the Bali Buton Asphalt Association which was still low due to the lack of optimal participation in budgeting, environmental uncertainty, leadership style, and budgetary adequacy. The reason for choosing this location is based on several considerations. The first is to prove whether there is indeed an influence on budgetary participation, environmental uncertainty, leadership style, and budgetary adequacy on managerial performance. Second, on the basis of the ease of obtaining data, the time available and the cost relief in conducting research.

In this study, the population is all construction service companies in Bali, amounting to 309 companies. The technique of determining the sample, in this case, is to use a purposive sampling method. There are 22 construction service companies incorporated in AABI in Bali. Each company is taken by 4 respondents who hold positions as directors, general superintendent/site manager, project finance department and field supervisors who participate in preparing the budget. So the number of respondents selected was $22 \times 4=88$ respondents.

In conducting data analysis, the steps that researchers do are transforming ordinal data into interval data with the MSI method, formulating regression models, assessing the goodness of fit regression models and testing hypotheses. 


\section{Results and Discussions}

\section{Moderated Regression Analysis (MRA)}

Moderated Regression Analysis (MRA) or interaction test is a special application of linear multiple regression where the regression equation contains elements of interaction (multiplication of two or more independent variables) to determine the magnitude of the effect of Budgetary Participation (X1) on Managerial Performance (Y) with Environmental Uncertainty (X2), Leadership Style (X3), and Budgetary Adequacy (X4) as moderating. The results of the regression analysis can be seen in Table 1 as follows:

Tabel 1

Moderated Regression Analysis (MRA)

\begin{tabular}{|c|c|c|c|c|c|c|}
\hline \multirow[b]{2}{*}{ Model } & & \multicolumn{2}{|c|}{$\begin{array}{l}\text { Unstandardized } \\
\text { Coefficients }\end{array}$} & \multicolumn{2}{|c|}{$\begin{array}{l}\text { Standardized } \\
\text { Coefficients }\end{array}$} & \multirow[b]{2}{*}{ Sig. } \\
\hline & & B & Std. Error & Beta & $\mathrm{t}$ & \\
\hline 1 & (Constant) & 85,563 & 20,815 & & 4,111 & 0,000 \\
\hline & $\mathrm{X}_{1}$ & $-3,525$ & 1,080 & 3,376 & $-3,263$ & 0,002 \\
\hline & $\mathrm{X}_{2}$ & $-0,450$ & 0,530 & $-0,905$ & $-0,848$ & 0,399 \\
\hline & $\mathrm{X}_{3}$ & 0,211 & 0,536 & 0,659 & 0,394 & 0,695 \\
\hline & $\mathrm{X}_{4}$ & $-0,935$ & 3,110 & $-0,556$ & $-0,301$ & 0,764 \\
\hline & $\mathrm{X}_{1} \mathrm{X}_{2}$ & 0,049 & 0,023 & 5,078 & 2,119 & 0,037 \\
\hline & $\mathrm{X}_{1} \mathrm{X}_{3}$ & $-0,004$ & 0,022 & $-0,542$ & $-0,185$ & 0,854 \\
\hline & $\mathrm{X}_{1} \mathrm{X}_{4}$ & 0,002 & 0,127 & 0,570 & 0,173 & 0,863 \\
\hline & $\mathrm{R}$ & $0,926^{\mathrm{a}}$ & & & & \\
\hline & $\mathrm{R}^{2}$ & 0,857 & & & & \\
\hline & Adjusted $\mathrm{R}^{2}$ & 0,845 & & & & \\
\hline & F Count & 68,650 & & & & \\
\hline & Significance F & $0,000^{\mathrm{a}}$ & & & & \\
\hline
\end{tabular}

Primary Data, 2019

\section{The Effect of Budgetary participation on Managerial Performance}

The first hypothesis testing ( $\mathrm{H} 1)$ has a value of $\mathrm{b}=-3.525$ with a significance level of 0.002 ( $\mathrm{sig}<0.05)$, so $\mathrm{H} 1$ is rejected. So budget participation has a negative effect on managerial performance. This shows that the higher budget participation, the managerial performance will tend to increase. This result is not in line with research by Yusfaningrum \& Ghozali (2005) and Lestari (2008), which states that there is a positive relationship between budgetary participation and managerial performance. Some researchers include variables to better explain the relationship between budgetary participation and managerial performance. Brownell \& Mclnnes (1986), include motivation variables that rely on expectations theory as intervening variables to examine the relationship between budgetary participation and managerial performance. The results of the study found evidence that motivation and participation in budgeting had a direct relationship with performance. In this case, someone who is actively involved in budgetary participation will cause a person's performance to improve. So it can be explained the relationship between budgetary participation on managerial performance is that if a participant has high participation then the performance will increase. These conditions cause participants to be trusted and relied on in carrying out their work so that they can run well and get the expected results.

The Effect of Environmental Uncertainty in Moderating the Relationship of Budgetary participation in Managerial Performance

The first hypothesis testing (H2) has a value of $b=0.049$ with a significance level of 0.037 ( $\mathrm{sig}<0.05$ ) so that $\mathrm{H} 2$ is accepted. So environmental uncertainty reinforces the influence of budgetary participation on managerial performance.

Tokilov, D. U., Suputra, I. D. G. D., \& Rasmini, N. K. (2019). Effect of budgetary participation in managerial performance with environmental uncertainty, leadership style, and budgetary adequacy as a moderating variable. International Research Journal of Management, IT and Social Sciences, 6(6), 50-57. https://doi.org/10.21744/irjmis.v6n6.752 
This shows that the higher the environmental uncertainty, the effect of budgetary participation tends to increase on managerial performance. The presence of environmental uncertainty variables strengthens the relationship between participation in budgeting and managerial performance. The results of this study are in line with the opinion of Govindarajan (1986) in Rahayu (1999) who tested environmental uncertainty variables measured subjectively to examine the relationship between budgetary participation with managerial attitudes and performance with the higher environmental uncertainty results, the greater participation in managerial performance, and in conditions of high environmental uncertainty, participation has a greater influence on managerial attitudes and motivations.

The Effect of Leadership Style in Moderating the Relationship of Budgetary participation in Managerial Performance

The first hypothesis testing (H3) has a value of $b=-0.004$ with a significance level of 0.854 ( $\mathrm{sig}<0.05$ ), so H3 is rejected. So the leadership style weakens the influence of budgetary participation on managerial performance. This shows that the leadership style which is oriented towards the existence of mutual trust and kinship between superiors and subordinates tends to weaken the influence of budgetary participation on managerial performance. The results of this study give results that are not the same as Coster \& Fertakis (1968), research showing that the style of consideration leadership has a positive impact on the existence of a budgeting drive and Sumarno (2005), in his research states that the effectiveness of budgetary participation on managerial performance is strongly influenced by management leadership style. However, the results of this study are consistent, research which shows insignificant results between participation with contingent leadership style factors on managerial performance. The insignificance of leadership style variables to the relationship between budgetary participation and managerial performance is due to the Director as the supervisor participating in setting goals and setting goals based on a definition limited to a group of top management. The budget will be used both as a mechanism to inform lower-level managers about what top management wants to achieve and to control peoples spending and motivate the performance.

\section{Effect of Budgetary Adequacy in Moderating the Relationship of Budgetary Participation in Managerial Performance}

The first hypothesis testing (H4) has a value of $b=0.002$ with a significance level of 0.863 (sig <0.05), so $\mathrm{H} 4$ is rejected. So the budgetary adequacy weakens the influence of budgeting participation on managerial performance. The budgetary adequacy has not been able to give employees confidence that they have enough budget to work in accordance with their duties and functions. If employees believe that the organization is responsible for ensuring that employees receive budgetary adequacy support, then the budgetary adequacy might increase employee ties to the organization (Nouri \& Parker, 1998). Nouri \& Parker (1998), argue that workers with budget support generally have better performance than workers who are not supported with a sufficient budget. The success of individuals and organizations depends on circumstances where subordinates can receive adequate budget support (Yunita, 2011). The results of this study are not in line with research conducted by Paters (1971), finding the budgetary adequacy as a situational factor that will affect managerial performance. However, the results of this study are in line with the research of Sinuraya (2011), which states there is no relationship between budgetary adequacy and improved performance.

\section{Determination Coefficient Test}

The coefficient of determination test is done to find out how far the ability of the independent variable (independent) to explain the dependent variable (dependent), this can be seen from the value of $\mathrm{R}^{2}$, namely adjusted $\mathrm{R}^{2}$. Based on the calculation results, the adjusted $\mathrm{R} 2$ value of 0.857 is obtained. This implies that 85.7 percent of variations in managerial performance variables can be explained by budgetary participation variables, environmental uncertainty, leadership style, and budgetary adequacy, while the remaining 14.3 percent is effect by other factors not included in the model research.

\section{Model Feasibility Test (F Test)}

This test aims to determine whether the regression model used in this study is feasible or not. Based on the regression results obtained the calculated $F$ value of 68.650 with a significance level of 0,000 . Because the significance of the $F$ count is less than 0.05 , it can be concluded that the regression model is used to determine the effect of budgetary participation on managerial performance by moderating environmental uncertainty, leadership style, and budgetary adequacy. 


\section{Research Limitations}

This research still has limitations so it still needs to be refined. This study uses questionnaire measurements that might cause perceptual bias, so future research can use experiments to avoid perception bias.

\section{Conclusion}

A contracting company incorporated in AABI in Bali Province needs to pay more attention to budgetary preparation, by opening opportunities for employees to discuss budget issues with superiors, motivating employees to contribute to budget preparation. Need to pay attention to the preparation of the budget and environmental uncertainty to improve managerial performance by providing knowledge to employees about methods that can be used in achieving company goals. To improve managerial performance where every employee both superiors and subordinates can be more relaxed or relaxed in providing explanations or in work, can support to continue to participate, there is openness when experiencing obstacles while working so that it can be resolved, leaders can be more polite and friendly towards subordinates so that subordinates feel more valued, and are always honest about the condition of the company to improve managerial performance by giving confidence to subordinates that the company budget is sufficient to complete the work being done.

Conflict of interest statement

The authors declared that they have no competing interest.

Statement of authorship

The authors have a responsibility for the conception and design of the study. The authors have approved the final article.

\section{Acknowledgments}

We thank the editor of IRJMIS for their valuable time, support and advice.

Tokilov, D. U., Suputra, I. D. G. D., \& Rasmini, N. K. (2019). Effect of budgetary participation in managerial performance with environmental uncertainty, leadership style, and budgetary adequacy as a moderating variable. International Research Journal of Management, IT and Social Sciences, 6(6), 50-57. https://doi.org/10.21744/irjmis.v6n6.752 


\section{References}

Brownell, P., \& McInnes, M. (1986). Budgetary participation, motivation, and managerial performance. Accounting review, 587-600.

Chenhall, R. H., \& Morris, D. (1986). The impact of structure, environment, and interdependence on the perceived usefulness of management accounting systems. Accounting Review, 16-35.

De Coster, T. D., \& Fertakis, P. J. 1968. Budget-induced pressure and its relationship to supervisory behavior. Journal of Accounting research (Autumn), 237-246.

Falikhatun, F. (2017). Pengaruh Partisipasi Penganggaran terhadap Budgetary Slack dengan Variabel Pemoderasi Ketidakpastian Lingkungan dan Kohesivitas Kelompok. Riset Akuntansi dan Keuangan Indonesia, 6(2), 207-221. https://doi.org/10.23917/reaksi.v6i2.3557

Fiedler, F. E. (1967). A theory of leadership effectiveness. mcgraw-hill series in management.

Ghozali, I., \& Yusfaningrum, K. (2005). Analisis Pengaruh Partisipasi Anggaran terhadap Kinerja Manajerial melalui Komitmen Tujuan Anggaran dan Job Relevant Information (JRI) sebagai Variabel Intervening. Penelitian terhadap Perusahaan Manufaktur di Indonesia), SNA VIII, Solo.

Govindarajan, V. (1986). Decentralization, strategy, and effectiveness of strategic business units in multibusiness organizations. Academy of Management Review, 11(4), 844-856. https://doi.org/10.5465/amr.1986.4284099

Gul, F. A., \& Chia, Y. M. (1994). The effects of management accounting systems, perceived environmental uncertainty and decentralization on managerial performance: a test of three-way interaction. Accounting, Organizations and Society, 19(4-5), 413-426. https://doi.org/10.1016/0361-3682(94)90005-1

Haryanti, T. (2012). Analisis Perilaku Harga dalam Pemasaran Cabai Merah (Capsicum Annum L.) di Kabupaten Sragen. Skripsi. Jurusan Sosial Ekonomi Pertanian. Fakultas Pertanian. Universitas Salemba Empat.

Kenis, I. (1979). Effects of budgetary goal characteristics on managerial attitudes and performance, the accounting review.

Kren, L. (1992). Budgetary participation and managerial performance: The impact of information and environmental volatility. Accounting Review, 511-526.

Lamba, A., Allo, P., \& Lamba, R. (2019). Effect of fiscal decentralization policy of regional economic imbalances towards economy growth in Eastern Indonesia. International Journal of Social Sciences and Humanities, 3(2), 112127. https://doi.org/10.29332/ijssh.v3n2.298

Lestari, S., \& Sudaryono, E. A. (2008). Pengaruh stock split: Analisis likuiditas saham pada perusahaan go public di Bursa Efek Indonesia dengan memperhatikan pertumbuhan dan ukuran perusahaan. Jurnal Bisnis dan Akuntansi, 10(3), 139-148. https://doi.org/10.34208/jba.v10i3.233

Milani, K. (1975). The relationship of participation in budget-setting to industrial supervisor performance and attitudes: a field study. The accounting review, 50(2), 274-284.

Musyarofah, S. (2004). Pengaruh Penggunaan Anggaran dan Gaya Manajemen terhadap Hubungan antara Perubahan Strategik dan Kinerja Organisasi. Indonesian Journal of Accounting and Auditing, 8(1).

Nouri, H., \& Parker, R. J. (1998). The relationship between budget participation and job performance: the roles of budget adequacy and organizational commitment. Accounting, Organizations and society, 23(5-6), 467-483. https://doi.org/10.1016/S0361-3682(97)00036-6

Paters, J., \& Dumong, W. (1971). The Strategy in Introducing Constraints in the Computers Models for Optimizing Machining Conditions. In Annals of CIRP.

Putri, Y. K. W., \& Sujana, I. K. (2018). The influence of bid-ask spread and leverage on earnings management with good corporate governance as moderating variable. International Research Journal of Management, IT and Social Sciences, 5(3), 8-21.

Rahayu, I. (1999). Pengaruh Ketidakpastian Lingkungan terhadap Partisipasi Penganggaran dan Kinerja Manajerial. Indonesian Journal of Accounting and Auditing, 3(2), 123-133.

Riyanto, B. (1997). Dasar-dasar Pembelanjaan Perusahaan Perusahaan.

Sinuraya, C. (2011). Pengaruh Partisipasi Penyusunan Anggaran terhadap Kinerja Manajer: Peran Kecukupan Anggaran dan Job-Relevant Information sebagai Variabel Intervening. Jurnal Akuntansi Maranatha, 1(1), 17-39. https://doi.org/10.28932/jam.v1i1.380

Sumarno, J. (2005). Pengaruh Komitmen Organisasi dan Gaya Kepemimpinan Terhadap Hubungan Antara Partisipasi Anggaran Dengan Kinerja Manajerial. Jurnal SNA, 8, 586-616.

Supriyono, R. S. (2004). Pengaruh Variabel Intervening Kecukupan Anggaran dan Komitmen Organisasi terhadap Hubungan Antara Partisipasi Penganggaran dan Kinerja Manajer di Indonesia. Journal of Indonesian Economy and Business, 19(3). https://doi.org/10.22146/jieb.6602 
Yanti, N. M. Y. W. A., \& Dwirandra, A. (2019). The effect of profitability in income smoothing practice with good corporate governance and dividend of payout ratio as a moderation variable. International Research Journal of Management, IT and Social Sciences, 6(2), 12-21. https://doi.org/10.21744/irjmis.v6n2.601

Tokilov, D. U., Suputra, I. D. G. D., \& Rasmini, N. K. (2019). Effect of budgetary participation in managerial performance with environmental uncertainty, leadership style, and budgetary adequacy as a moderating variable. International Research Journal of Management, IT and Social Sciences, 6(6), 50-57. https://doi.org/10.21744/irjmis.v6n6.752 